\title{
REVIEW OF FIRE AND EXPLOSION HAZARDS OF FLIGHT VEHICLE COMBUSTIBLES
}

By Robert W. Van Dolah, Michael G. Zabetakis,

David S. Burgess, and George S. Scott

* * * * * * * * * information circular 8137

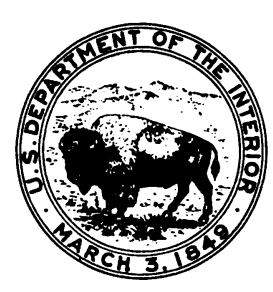

UNITED STATES DEPARTMENT OF THE INTERIOR Stewart L. Udall, Secretary

BUREAU OF MINES

Marling J. Ankeny, Director 